\title{
PERAN MEDIASI ASIMETRI INFORMASI DAN INSENTIF DALAM KASUS KESENJANGAN ANGGARAN PENDAPATAN ASLI DAERAH
}

\author{
Budi Barata Kusuma Utami \\ Rusdi Akbar \\ Universitas Ahmad Dahlan \\ Universitas Gajah Mada \\ budi.utami@act.uad.ac.id
}

\begin{abstract}
In the private sector budget slack are more dominant due to economic motivational factors such as incentives. In the local government sector there are organizations that operate as profit centers and can be assumed to be the same as the private sector. This study purpose to show empirical evidence about the mediation of information asymmetry and incentives in the phenomenon of budget slack in the LocallyOwn Source Revenue Plan. Data collection techniques using primary data. The sample uses Echelon IIIa and IVa officials who work in local government institutions, namely the bureaucrats for collecting local revenue. This study results information asymmetry mediate to the relationship of participation to budget slack. While incentives do not mediate to the relationship of information asymmetry to budget slack. Results of this study provides empirical evidence that economic factors are not encourage of budget slack in the local government sector.
\end{abstract}

Keywords: Participation, Information Asymmetry, Incentives, Budget Slack, LocallyOwn Source Revenue

\section{PENDAHULUAN}

Undang-undang No. 32 tahun 2004 tentang Pemerintahan Daerah memberikan efek mengenai perubahan sistem pemerintahan negara Indonesia yang semula menganut pola sentralisasi menjadi desentralisasi. Tujuan lain dari adanya otonomi daerah adalah memperkuat perekonomian daerah dengan cara memberikan otonomi kepada pemerintah lokal untuk mengelola sumber daya daerah dengan menggunakan anggaran yang mereka susun sendiri, sedangkan anggaran digunakan untuk menunjukan estimasi kinerja selama jangka waktu tertentu guna mengelola sumber daya daerah itu sendiri.

Sebelum reformasi birokrasi model partisipasi dalam penganggaran masih menggunakan model top-down, artinya anggaran ditentukan oleh atasan sehingga bawahan tidak berpartisipasi dalam proses penentuan anggaran. Sebaliknya setelah reformasi birokrasi model partisipasi dalam proses penganggaran berubah menjadi bottomup, artinya eksekutif daerah yang di delegasikan dengan dinas-dinas ikut berpartisipasi dalam proses penyusunan target anggaran (Halim dan Kusufi, 2014).

Gibran dan Skewat (2009) mengungkapkan bahwa sejarah dari teori penganggaran hanya sebatas mekanisme di lapangan tanpa memperhatikan aspek-aspek yang melingkupinya. Fenomena proses penganggaran terpisah dari nilai-nilai, perilaku, makna, dan lingkungan sosial politik, sehingga penelitian ini mengarahkan pada aspek keperilakuan dalam kesenjangan anggaran yang terajdi pada pemerintahan daerah khususnya kasus perencanaan pendapatan daerah. 


\section{JURNAL OPTIMUM, Volume 10, Nomor 1 Maret 2020}

Anthony dan Govindarajan (2005) mendefinisi kesenjangan anggaran adalah perbedaan antara jumlah yang direncanakan dengan estimasi hasil yang akan didapat. Young (1985) mendefinisi kesenjangan anggaran adalah menyatakan menyatakan jumlah produktifitas yang lebih rendah ketika agen dalam pusat pertanggungjawaban diberikan hak untuk partisipasi dalam menentukan standar kerja yang digunakan untuk menilai kinerjanya. Dengan demikian dapat disimpulkan bahwa dalam proses perencanaan anggaran menyatakan rencana anggaran lebih rendah dalam hal pendapatan sebagai standar penilaian kinerja sehingga akan nampak perbedaan antara rencana dan hasil yang dicapai.

Kennyataanya dalam penganggaran tepatnya proses perencanaan terjadi perilaku disfungsional oleh pihak eksekutif daerah yang berpartisipasi dalam penyusunan anggaran. Pengelola anggaran daerah tidak berkerja secara optimal selain itu juga menyembunyikan informasi yang dimiliki kepada pihak atasan mereka yaitu legislatif daerah. Realitas yang dapat dirasakan dalam hal ini adalah fenomena kesenjangan anggaran khususnya pada sektor pendapatan asli daerah (PAD) dengan cara melakukan perencanaan target anggaran lebih rendah dengan tujuan untuk mempermudah pencapaian anggaran.

Jika berbicara tentang kesenjangan anggaran pada organisasi profit pemerintah daerah maka dapat dilihat persamaan dengan fenomena kesenjangan anggaran pada kasus organisasi profit karena fungsinya sama yaitu sebagai profit centre. Untuk itu penelitian ini mengambil beberapa penelitian terdahulu tentang kesenjangan anggaran pada sektor profit sebagai persamaan analogi. Beberapa penelitian mengenai partisipasi anggaran menunjukan bahwa partisipasi memiliki hubungan terhadap kesenjangan anggaran melalui beberapa variabel. Douglas dan Wier (2000) mengungkapkan bahwa partisipasi dalam penganggaran mempunyai pengaruh tidak langsung terhadap terciptanya kesenjangan anggaran. Hubungan tidak langsung tersebut dimediasi oleh asimetri informasi.

Beberapa penelitian terdahulu seperti Schiff dan Lewin (1970) menyatakan bahwa ketika agen bawah memberikan informasi yang bias kepada atasan dalam proses penganggaran maka hal tersebut mendorong terjadinya kesenjangan anggaran. Pope (1984) mengungkapkan bahwa agen yang berpartisipasi dalam penganggaran cenderung menyembunyikan atau merahasiakan informasi dalam proses penganggaran.

Harrell dan Harrison mengungkapkan bahwa meskipun asimetri informasi memberikan kesempatan untuk menciptakan kesenjangan anggaran, namun hal tersebut tidak cukup untuk mendorong terciptanya kesenjangan anggaran. Asimetri informasi tersebut digunakan para agen yang berpartisipasi dalam proses penentuan target anggaran untuk mendapatkan kemakmuran ekonomik berupa insentif.

Insentif untuk pencapaian anggaran disebutkan dalam Peraturan Pemerintah Nomor 69 Tahun 2010, apabila kinerja pengelola pendapatan tercapai maka akan diberikan insentif, sehingga hal ini masih menarik untuk diteliti terkait dengan masalah kesenjangan anggaran Pendapatan Asli Daerah. Mengacu pada pernyataan Harrell dan Harrison (1994) mengenai ketidakcukupan asimetri informasi memunculkan sebuah pertanyaan apakah ketidakcukupan asimetri informasi terkait oleh insentif. Selain itu tujuan dalam penelitian ini untuk menemukan bukti empirik tentang asimetri informasi dan insentif yang menyebabkan kesenjangan anggaran dalam perencanaan anggaran Pendapatan Asli Daerah terjadi.

Lowe dan Shaw (1968) mengungkapkan bahwa agen menciptakan kesenjangan anggaran karena dua faktor, yaitu karena adanya kepentingan pribadi dan rasionalitas ekonomi atau keinginan mendapatkan insentif atas hasil pencapaian anggaran, sehingga peneliti berasumsi ada rasionalitas ekonomi 


\section{BUDI BARATA KUSUMA UTAMI, RUSDI AKBAR \\ Peran Mediasi Asimetri Informasi Dan Insentif Dalam Kasus Kesenjangan Anggaran \\ Pendapatan Asli Daerah}

berupa motivasi mendapatkan insentif menjadi salah satu faktor terciptanya kesenjangan anggaran. Jensen dan Meckling (1976) bahwa masalah keagenan terjadi karena adanya konflik kepentingan antara kedua pihak yaitu agen dan prinsipal dalam hal ini eksekutif daerah dan legislatif daerah. Peneliti berasumsi bahwa insentif menjadi sebuah tujuan dalam proses pencapaian anggaran Pendapatan Asli Daerah oleh pihak pengelola pendapatan Pemerintah Daerah.

\section{REVIEW LITERATUR DAN HIPOTESIS}

\section{Teori Keagenan}

Jensen dan Meckling (1976) menyatakan bahwa masalah keagenan terjadi karena adanya konflik kepentingan antara kedua belah pihak yaitu agen dan prinsipal dalam hal ini eksekutif daerah dan legislatif daerah. Eisenhardt (1989) mengungkapkan bahwa teori keagenan merupakan teori mengenai sifat dasar manusia yang mementingkan diri sendiri, memiliki daya pikir terbatas serta menghindari risiko sehingga hal tersebut menimbulkan konflik antara kepentingan agen dan prinsipal dalam hal ini eksekutif dan legislatif.

Gudono dalam Halim dan Kusufi (2014) mengungkapkan bahwa teori keagenan menimbulkan dua masalah: pertama masalah tentang konflik agen dan prinsipal, kedua masalah tentang pemilihan agen. Masalah prinsipal agen adalah masalah yang timbul karena agen melakukan tindakan yang menguntungkan dirinya sendiri dengan mengeksploitasi keunggulan informasi yang dimilikinya, namun merugikan pihak prinsipal.

Jika ditarik dalam sistem pemerintahan, maka agen adalah eksekutif daerah yang berkerja dalam dinas yang mengelola Pendapatan Asli Daerah. Dalam kasus kesenjangan anggaran Pendapatan Asli Daerah direncanakan lebih rendah dibanding kemampuan realisasi dengan tujuan untuk kemudahan pencapaian target kinerja sehingga mendapatkan insentif atas kinerja tersebut.

\section{Partisipasi}

Anthony dan Govindarajan (2005) menyatakan bahwa partisipasi anggaran adalah proses individu terlibat dalam anggaran dan mempunyai pengaruh dalam proses penyusunan anggaran. Milani (1975) menyatakan bahwa tingkat partisipasi dan pengaruh bawahan terhadap proses penentuan target anggaran merupakan faktor yang membedakan anggaran partisipatif dan nonpartisipatif. Brownell (1980) menyatakan bahwa partisipasi merupakan proses yang melibatkan individu dalam penyusunan anggaran dan mempunyai pengaruh terhadap penyusunan tujuan anggaran.

Halim dan Kusufi (2014) menyatakan bahwa sebelum era reformasi birokrasi model penganggaran masih menggunakan model topdown, artinya anggaran ditentukan oleh atasan sehingga bawahan tidak berpartisipasi. Hal tersebut mempunyai kelemahan bahwa model top-down dianggap tidak tepat oleh para bawahan yang bersentuhan langsung dengan aktivitas mencari pendapatan khususnya dalam hal ini adalah aktivitas mengumpulkan Pendapatan Asli Daerah.

Model kedua adalah bottom up yaitu bawahan berpartisipasi dalam proses perencanaan anggaran dan menentukan target yang akan dicapai. Kelemahan pada model Partisipasi ini adalah munculnya perilaku disfungsional dengan cara merencanakan target pencapaian lebih rendah daripada potensi yang sesungguhnya. Dapat ditarik simpulan bahwa Partisipasi dalam proses penyusunan anggaran merupakan keikutsertaan pihak-pihak yang mempunyai kepentingan dalam anggaran untuk menentukan target anggaran tentunya dalam hal ini target pencapaian Pendapatan Asli Daerah.

\section{Kesenjangan Anggaran}

Merchant (1985) menyebutkan bahwa prilaku disfungsional dalam proses penyusunan anggaran terjadi seseorang berupaya ingin menerima sumber-sumber ekonomi melebihi yang diperlukan dengan cara mengurangi 


\section{JURNAL OPTIMUM, Volume 10, Nomor 1 Maret 2020}

kemampuan produktifitas organisasi dari seharusnya. Siegel dan Marconi (1989) mendefinisi kesenjangan anggaran sebagai perbedaan antara sumber daya yang sebenarnya dibutuhkan untuk melaksanakan suatu pekerjaan dengan sumber daya yang sesungguhnya dihasilkan dalam anggaran, hal ini dengan menyatakan kemapuan estimasi menghasilkan Pendapatan Asli Daerah lebih rendah dibandingkan dengan realisasi.

Hal ini terjadi karena kinerja eksekutif daerah dinilai dari pencapaiannya terhadap target anggaran. Siegel dan Marconi (1989) mengungkapkan bahwa kesenjangan anggaran dapat meningkatkan kesempatan bagi pembuat anggaran untuk menurunkan risiko mendapatkan punishment atau pemberhentian jabatan. Lukka (1988) menyatakan bahwa anggaran yang disusun dapat dikatakan terjadi kesenjangan apabila agen menyusun perencanaan target lebih rendah dari target perencanaan yang terbaik untuk masa depan sehingga rendahnya target anggaran menyebabkan lebih mudah dicapai. Apabila kesenjangan anggaran diciptakan terlalu besar sehingga target anggaran mudah dicapai maka fungsi anggaran sebagai alat standar penilaian kinerja menjadi tidak efektif khususnya pada penilaian kinerja menghasilkan Pendapatan Asli Daerah.

\section{Asimetri Informasi}

Teori Keagenan menunjukan bahwa asimetri informasi dapat menyebabkan partisipasi anggaran menuju terjadinya kesenjangan anggaran. Munculnya asimetri informasi adalah ketika agen memiliki informasi tidak simetris dengan atasannya. Informasi tersebut dapat mempengaruhi pengambilan keputusan mengenai target anggaran yang akan dicapai (Baimans dan Evans, 1983). Dunk (1993) menyatakan bahwa pemberian akses informasi kepada atasan dapat mengurangi asimetri informasi antara atasan dan bawahan seperti dalam kasus informasi target pencapaian Pendapatan Asli Daerah.
Prinsipal mempunyai pengetahuan yang lebih dibandingkan agen mengenai unit pertanggungjawaban atau sebaliknya agen memiliki pengetahuan informasi lebih baik dibanding prinsipal. Apabila atasan memiliki pengetahuan informasi yang lebih dibanding agen maka akan muncul tuntutan yang lebih besar dari prinsipal kepada agen untuk meningkatkan target pencapaian anggaran dalam hal ini target pencapaian Pendapatan Asli Daerah. Selanjutnya apabila agen memiliki pengetahuan informasi yang lebih baik dibanding prinsipal maka yang agen akan membuat target anggaran lebih rendah dan mudah dicapai. Keadaan yang menunjukan salah satu pihak memiliki pengetahuan informasi lebih baik dari pihak lainnya disebut sebagai asimetri informasi. Menurut Dunk (1993) asimetri informasi terjadi ketika agen memiliki informasi lebih baik dibanding dengan prinsipal dalam organisasi tertentu.

Chow et al (1988) menyatakan bahwa agen memiliki informasi yang lebih akurat dibanding prinsipal. Informasi tersebut digunakan untuk mempengaruhi standar pengukuran kinerja dalam pencapaian anggaran. Adanya asimetri informasi sangat terkait erat dengan penentuan target anggaran yang akan dicapai, sehingga asimetri informasi merupakan salah satu faktor yang dapat menyebabkan ternjadinya kesenjangan anggaran.

\section{Insentif}

Anthony dan Govindarajan (2007) menyebutkan bahwa terdapat dua jenis insentif. Insentif positif atau disebut sebagai reward bertujuan untuk meningkatkan kepuasan dari kebutuhan individu, sedangkan Insentif negatif atau disebut sebagai punishment bertujuan untuk menurunkan kepuasan dari kebutuhan individu.

Menurut Peraturan Pemerintah Nomor 69 Tahun 2010 tentang pemberian insentif disebutkan bahwa insentif merupakan tambahan penghasilan yang diberikan sebagai penghargaan atas kinerja tertentu dalam 


\section{BUDI BARATA KUSUMA UTAMI, RUSDI AKBAR \\ Peran Mediasi Asimetri Informasi Dan Insentif Dalam Kasus Kesenjangan Anggaran \\ Pendapatan Asli Daerah}

melaksanakan pemungutan Pajak dan Retribusi. Sumber insentif diambil dari pendapatan Pajak Daerah dan Retribusi Daerah sesuai dengan ketentuan peraturan perundangundangan (Pasal 5), besaran insentif yang diberikan untuk provinsi paling tinggi 3\% dan untuk Kabupaten/Kota sebesar 5\% dari rencana penerimaan Pajak dan Retribusi (Pasal 6 Ayat 1).

Dalam konteks Pemerintah Daerah, eksekutif adalah Badan Keuangan dan Aset Daerah selaku pengelola Pendapatan Asli Daerah yang kinerjanya diukur dan dinilai dengan insentif. Apabila dihubungkan dengan teori keagenan dengan memiliki keunggulan informasi dibandingkan dengan legislatif daerah maka eksekutif daerah akan bertindak menguntungkan diri sendiri dengan memanfaatkan informasi yang dimiliki untuk membuat target pencapaian anggaran yang rendah dan lebih mudah dicapai untuk mendapatkan Insentif.

\section{Pengembangan Hipotesis \\ Partisipasi, Asimetri Informasi dan Kesenjangan Anggaran}

Partisipasi anggaran merupakan proses pengambilan keputusan dalam penyusunan anggaran yang membawa dampak di masa depan bagi pihak yang berpartisipasi dalam penyusunan anggaran. Lukka (1988) menyatakan bahwa tingkat partisipasi yang tinggi dalam proses penganggaran memberikan kesempatan kepada bawahan untuk menciptakan kesenjangan anggaran.

Apabila keterlibatan agen dalam pemerintah daerah pada proses penyusunan anggaran pendapatan disalahgunakan demi memenuhi kepentingan pribadi mereka maka akan menimbulkan apa yang disebut sebagai kesenjangan anggaran. Apabila dikaitkan dengan masalah penilaian prestasi kinerja yang ditentukan berdasarkan target pencapaian anggaran. Eksekutif melakukan upaya menentukan target Pendapatan Asli Daerah yang rendah. Hasil penelitian Falikhatun
(2007) menunjukan bahwa partisipasi berpengaruh terhadap kesenjangan anggaran.

Eksekutif daerah terlibat langsung dalam proses penyusunan anggaran untuk menentukan target Pendapatan Asli Daerah yang cenderung disusun mudah dicapai. Anthony dan Govindarajan (2005) menyatakan bahwa dalam teori keagenan asimetri muncul ketika prinsipal memberikan wewenang kepada agen untuk mengatur tanggung jawab yang dimiliki. Kondisi ketidakpastian menyebabkan informasi yang dimiliki bawahan melebihi informasi yang dimiliki prinsipal. Terkait dengan teori keagenan, individu yang berpartisipasi dalam perencanaan anggaran cenderung memanfaatkan kelebihan informasi tersebut guna mempengaruhi target pencapaian anggaran dan hipotesis yang diajukan adalah:

$\mathbf{H}_{1}$ : Asimetri informasi memediasi hubungan partisipasi terhadap kesenjangan anggaran $\left(\mathrm{H}_{\mathrm{a}}\right)$.

\section{Asimetri Informasi, Insentif dan Kesenjangan Anggaran}

Shields dan Shields mengungkapkan bahwa masalah partisipasi dalam sistem penganggaran karena adanya asimetri informasi. Asimetri informasi diasumsikan bahwa agen mempunyai informasi melebihi prinsipal. Christensen (1982) juga mengungkapkan bahwa ketika agen mempunyai informasi lebih banyak dibandingkan dengan prinsipal maka informasi tersebut digunakan untuk menyusun basis evaluasi penilaian kinerja.

Namun Harrell dan Harrison (1994) mengungkapkan bahwa meskipun asimetri informasi memberikan kesempatan untuk menciptakan kesenjangan anggaran, namun hal tersebut tidak cukup untuk mendorong terciptanya kesenjangan anggaran. Gomez dan Wiseman (1997) mengungkapkan bahwa insentif dapat dikembangkan dengan perilaku dalam konteks teori ekonomi dan pengambilan keputusan (decision theory). Selanjutnya Pepper dan Gore (2012) mengembangkan 
insentif menggunakan agency theory (teori keagenan) hasilnya menunjukan bahwa insentif sebagai pemicu behavioral agency (perilaku keagenan). Perilaku keagenan berwujud memanfaatkan perbedaan informasi yang dimiliki untuk mendapatkan insentif dengan menciptakan target pencapaian yang rendah.

Chow et al. (1988) mengungkapkan bahwa asimetri informasi dan pay scheme (truth dan slack) mendorong terjadinya kesenjangan anggaran dalam konteks hubungan partisipasi terhadap kesenjangan anggaran. Bento dan Ferreira (2006) mengungkapkan bahwa anggaran mempunyai peran sebagai alat evaluasi kinerja untuk memberikan insentif sehingga dalam konteks partisipasi dalam perencanaan anggaran Pendapatan Asli Daerah (PAD), asimetri informasi dalam mendorong terjadinya kesenjangan anggaran dengan mediasi insentif. Hal ini menunjukan bahwa terdapat behavioral agency, maka hipotesis yang diajukan adalah:

$\mathbf{H}_{2}$ : Insentif memediasi hubungan asimetri informasi terhadap

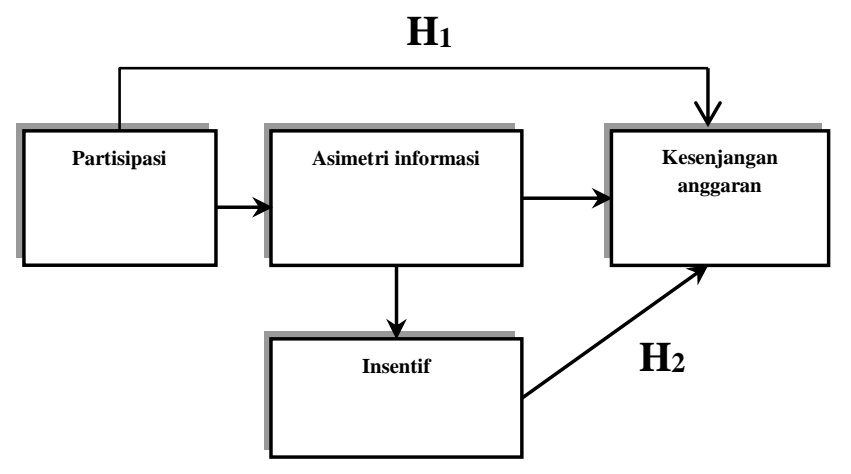

Model Penelitian

kesenjangan anggaran $\left(\mathrm{H}_{\mathrm{a}}\right)$.

\section{METODE PENELITIAN}

\section{Populasi dan Sampel}

Penelitian ini dilakukan pada Dinas Pendapatan Pengelolaan Keuangan dan Aset Provinsi Daerah Istimewa Yogyakarta dan lima Badan Keuangan dan Aset Daerah pada lima kabupaten, yaitu: Kabupaten Bantul, Kabupaten Sleman, Kabupaten Gunungkidul dan Kabupaten Kulonprogo dan Kabupaten Klaten. Objek penelitian adalah individu yang berkerja pada Badan Keuangan dan Aset Daerah yang mengelola pendapatan daerah. Metoda pemilihan sampel yang digunakan dalam penelitian ini adalah purposive sampling. Sampel dipilih berdasarkan kriteria tertentu dan memiliki tujuan untuk memastikan responden adalah pejabat yang terlibat proses penyusunan anggaran Pendapatan Asli Daerah. Oleh karena itu sampel dalam penelitian ini adalah pejabat Eselon IIIa dan Eselon Iva.

Data dikumpulkan menggunakan data primer melalui penyebaran kuesioner di lingkungan Dinas Pendapatan Pengelolaan Keuangan dan Aset Provinsi Daerah Istimewa Yogyakarta dan Badan Keuangan dan Aset Daerah. Data yang diperoleh akan dolah dengan alat statistik program SmartPLS.

HASIL PENELITIAN DAN PEMBAHASAN

Berikut merupakan tabel deskripsi mengenai profil responden penelitian terdiri dari jenis kelamin, tingkat pendidikan, dan masa kerja responden.

\section{Tabel 1}

Profil Responden

\begin{tabular}{|l|c|c|}
\hline Karakteristik & Jumlah & Presentase \\
\hline \multicolumn{3}{|c|}{ Jenis Kelamin } \\
\hline Pria & 17 & $42.5 \%$ \\
\hline Wanita & 23 & $57.5 \%$ \\
\hline Total & $\mathbf{4 0}$ & $\mathbf{1 0 0 \%}$ \\
\hline \multicolumn{3}{|c|}{ Tingkat Pendidikan } \\
\hline Diploma & 3 & $7.5 \%$ \\
\hline Strata 1 & 26 & $65 \%$ \\
\hline Strata 2 & 11 & $27.5 \%$ \\
\hline Total & $\mathbf{4 0}$ & $\mathbf{1 0 0 \%}$ \\
\hline \multicolumn{3}{|c|}{ Tingkat Eselon } \\
\hline III & 22 & $55 \%$ \\
\hline IV & 18 & $45 \%$ \\
\hline Total & $\mathbf{4 0}$ & $\mathbf{1 0 0} \%$ \\
\hline
\end{tabular}

\section{Evaluasi Model Pengukuran}

Hartono (2011) menyatakan bahwa validitas konstruk merupakan hasil yang 


\section{BUDI BARATA KUSUMA UTAMI, RUSDI AKBAR \\ Peran Mediasi Asimetri Informasi Dan Insentif Dalam Kasus Kesenjangan Anggaran Pendapatan Asli Daerah}

diperoleh dari suatu pengukuran yang sesuai dengan teori-teori yang digunakan untuk mendefinisi suatu konstruk. Validitas konstruk dibagi menjadi dua yaitu validitas konvergen dan validitas diskriminan. Gudono (2015) menyatakan bahwa ada beberapa hal yang perlu dicermati tentang penilaian goodness of fit pada outer model yang dilakukan dengan memperhatikan vaiditas konvergen, validitas diskriminan dan composite reliability. Hartono (2011) menyatakan bahwa validitas konvergen melihat nilai average variance explained, validitas diskriminan melihat skor cross loading 0,5-0,6 harus lebih besar dari 0,5 dan Gudono (2015) menyatakan composite reliability harus diatas 0,7 .

Tabel. 2

Construct Reliability Dan Validity

\begin{tabular}{|l|c|c|c|c|}
\hline & $\begin{array}{c}\text { AVE } \\
)\end{array}$ & $\begin{array}{c}\text { Composite } \\
\text { Reliability }\end{array}$ & $\mathrm{R}^{2}$ & $\begin{array}{c}\text { Cronbach' } \\
\text { s Alpha }\end{array}$ \\
\hline Partisipasi & 0,770 & 0,964 & & 0,958 \\
\hline Asimetri informasi & 0,871 & 0,964 & 0,461 & 0,951 \\
\hline Insentif & 0,763 & 0,865 & 0,009 & 0,692 \\
\hline $\begin{array}{l}\text { Kesenjangan } \\
\text { anggaran }\end{array}$ & 0,838 & 0,912 & 0,719 & 0,807 \\
\hline
\end{tabular}

Sumber: hasil olah data

\section{Uji validitas konvergen}

Hartono (2011) menyatakan bahwa kriteria nilai average variance explained harus diatas 0,50. Pada tabel 2 menunjukan bahwa nilai average variance explained pada setiap variabel laten memiliki nilai diatas 0,50. Variabel laten partisipasi memiliki nilai 0.770 , variabel laten asimetri informasi memiliki nilai 0.871 , variabel laten insentif memiliki nilai 0.763 , variabel kesenjangan anggaran memiliki nilai 0.838 .

\section{Uji validitas diskriminan}

Hartono (2011) menyatakan bahwa validitas konvergen dilihat pada skor loading. Sedangkan rule of thumb 0,5-0,7 sudah cukup atau lebih tinggi lebih baik. Pada tabel 3 menunjukan nilai skor loading setiap indikator pada variabel laten partisipasi, asimetri informasi, insentif, kesenjangan anggaran. Pada tabel dibawah menunjukan bahwa masing-masing skor pada indikator variabel laten menunjukan nilai diatas rule of thumbs 0.5-0.7.

Tabel 3.

\section{Cross Loading}

\begin{tabular}{|c|c|c|c|c|}
\hline & $\begin{array}{c}\text { Partisipas } \\
\text { i }\end{array}$ & $\begin{array}{c}\text { Asimetri } \\
\text { informasi }\end{array}$ & Insentif & $\begin{array}{c}\text { Kesenjangan } \\
\text { anggaran }\end{array}$ \\
\hline Part1 & 0,895 & & & \\
\hline Part2 & 0,886 & & & \\
\hline Part3 & 0,872 & & & \\
\hline Part4 & 0,885 & & & \\
\hline Part5 & 0,812 & & & \\
\hline Part6 & 0,899 & & & \\
\hline Part7 & 0,890 & & & \\
\hline Part8 & 0,880 & & & \\
\hline Asim1 & & 0,879 & & \\
\hline Asim2 & & 0,954 & & \\
\hline Asim3 & & 0,944 & & \\
\hline Asim4 & & 0,955 & & \\
\hline Ins1 & & & 0,843 & \\
\hline Ins2 & & & 0,902 & \\
\hline $\begin{array}{c}\text { Slack } \\
\text { 1 }\end{array}$ & & & & 0,937 \\
\hline $\begin{array}{c}\text { Slack } \\
\text { 2 }\end{array}$ & & & & 0,866 \\
\hline
\end{tabular}

Sumber : hasil olah data

\section{Uji reliabilitas}

Hartono (2011) menyatakan bahwa hasil uji reliabilitas dapat dilihat pada nilai cronbach's alpha dan nilai composite reliability. Konstruk dikatakan reliabel jika nilai cronbach's alpha diatas 0,6 dan nilai composite reliability diatas 0,7 . Pada tabel 2 variabel laten partisipasi memiliki nilai cronbach's alpha sebesar 0,958, variabel laten asimetri informasi memiliki nilai sebesar 0,951, variabel laten insentif memiliki nilai sebesar 0,692, variabel laten kesenjangan anggaran memiliki nilai sebesar 0,807. Selanjutnya pada tabel 2 nilai composite reliability untuk variabel laten partisipasi sebesar 0,964, variabel laten asimetri informasi memiliki nilai sebesar 0,964, variabel laten Insentif memiliki nilai sebesar 0,865 , variabel laten kesenjangan anggaran memiliki nilai sebesar 0,912 . 


\section{Evaluasi Model Struktural}

Hartono (2011) menyatakan bahwa model struktural dalam partial least square (PLS) dievaluasi dengan menggunakan $\mathrm{R}^{2}$ untuk konstruk dependen dan nilai t-values untuk setiap path dalam menguji signifikansi antar konstruk pada model struktural. Pada tabel 2 menunjukan bahwa besarnya hubungan partisipasi terhadap asimetri informasi sebesar 0,461 dan besarnya hubungan asimetri informasi terhadap kesenjangan anggaran sebesar 0,719 , artinya variabel laten partisipasi menjelaskan variabel laten asimetri informasi sebesar 0,461 dan variabel laten asimetri informasi menjelaskan variabel laten kesenjangan anggaran sebesar 0,719.

\section{Pengujian Hipotesis}

Pengujian hipotesis dengan menggunakan bootstraping pada program smartPLS. Berikut pada tabel 4 mengenai total effect menunjukan hasil evaluasi model.

Tabel 4.

Total Effect $(\mathbf{p}<0.05)$

\begin{tabular}{|c|c|c|c|c|c|}
\hline & $\begin{array}{c}\text { Original } \\
\text { Sample } \\
\text { (o) }\end{array}$ & $\begin{array}{c}\text { Sample } \\
\text { Mean }(\mathbf{M})\end{array}$ & $\begin{array}{l}\text { Stadad } \\
\text { Deviation } \\
\text { (STDEV }\end{array}$ & $\begin{aligned} \text { TStatistics } \\
\text { (|O/STDEV| }\end{aligned}$ & $P$ Valles \\
\hline $\begin{array}{l}\text { Partisipasi - } \\
>\text { Asimetri } \\
\text { informasi }\end{array}$ & $\begin{array}{c}0,67 \\
9\end{array}$ & 0,686 & 0,075 & 9,075 & $\mathbf{0 , 0 0 0}$ \\
\hline $\begin{array}{l}\text { Asimetri } \\
\text { informasi - } \\
> \\
\text { Kesenjagan } \\
\text { anggaran }\end{array}$ & $\begin{array}{c}0,44 \\
5\end{array}$ & 0,458 & 0,174 & 2,562 & 0,011 \\
\hline $\begin{array}{l}\text { Partisipasi - } \\
> \\
\text { Kesenjanga } \\
n \text { anggaran }\end{array}$ & $\begin{array}{c}0,65 \\
5\end{array}$ & 0,649 & 0,095 & 6,919 & $\mathbf{0 , 0 0 0}$ \\
\hline $\begin{array}{l}\text { Asimetri } \\
\text { informasi - } \\
\text { > Insentif }\end{array}$ & $\begin{array}{c}0,09 \\
5\end{array}$ & 0,073 & 0.219 & 0,435 & 0,664 \\
\hline $\begin{array}{l}\text { Insentif -> } \\
\text { Kesenjanga } \\
n \text { anggaran }\end{array}$ & $\begin{array}{c}0,22 \\
8\end{array}$ & 0,258 & 0,169 & 1,358 & 0,175 \\
\hline
\end{tabular}

Sumber : hasil olah data

$\mathbf{H}_{1}$ : Asimetri Informasi memediasi hubungan Partisipasi dan kesenjangan anggaran $\left(\mathrm{H}_{\mathrm{a}}\right)$.
Hasil pengujian pada tabel 4 menunjukan bahwa partisipasi memiliki hubungan terhadap asimetri informasi. Hal ini ditunjukan dengan nilai signifikansi sebesar 0,000 atau dibawah nilai 0,05 . Selanjutnya nilai signifikansi variabel asimetri informasi terhadap kesenjangan anggaran sebesar 0,011 atau dibawah nilai 0,05. Dengan demikian hasil tersebut menunjukan bahwa asimetri informasi merupakan variabel mediator hubungan partisipasi terhadap kesenjangan anggaran. Maka dapat dikatakan bahwa $\mathrm{H}_{1}$ dalam penelitian ini secara empirik terdukung. Hasil penelitian ini konsisten dengan Shields dan Shields (1998) dan Chirstensen (1982) yang menyatakan bahwa agen menggunakan informasi yang mereka miliki dalam proses partisipasi anggaran dan informasi tersebut digunakan untuk proses dasar dalam penyusunan target anggaran.

$\mathbf{H}_{2}$ : Insentif memediasi hubungan Asimetri Informasi terhadap Budget Slack $\left(\mathrm{H}_{\mathrm{a}}\right)$.

Hasil pengujian pada tabel 4 menunjukan bahwa asimetri informasi tidak memiliki hubungan terhadap insentif. Selanjutnya, insentif tidak memiliki hubungan terhadap kesenjangan anggaran. Hal ini dilihat dari nilai signifikansi sebesar 0,664 dan 0,175 atau diatas nilai 0,05 . Dengan demikian $\mathrm{H}_{\mathrm{a}}$ dalam penelitian ini secara empirik tidak dapat terdukung dan hasil tersebut menunjukan bahwa insentif bukan mediator hubungan antara asimetri informasi terhadap kesenjangan anggaran. Hasil dalam penelitian ini menunjukan inkonsisten dengan Harrell dan Harrison (1994) yang menyatakan asimetri informasi tidak cukup mendorong terjadinya kesenjangan anggaran sehingga perlu dimediasi oleh insentif. Penelitian ini memberikan bukti empirik bahwa asimetri informasi sebagai variabel mediator terjadinya kesenjangan anggaran dalam konteks rencana penentuan target anggaran Pendapatan Asli Daerah. 


\section{BUDI BARATA KUSUMA UTAMI, RUSDI AKBAR Peran Mediasi Asimetri Informasi Dan Insentif Dalam Kasus Kesenjangan Anggaran Pendapatan Asli Daerah}

\section{KESIMPULAN}

Penelitian ini memberikan bukti emperik bahwa asimetri informasi sebagai mediator hubungan partisipasi terhadap kesenjangan anggaran. Hal tersebut ditunjukan dengan nilai signifikansi hubungan partisipasi dan asimetri informasi sebesar 0,000 artinya partisipasi memiliki hubungan signifikan terhadap asimetri informasi, selanjutnya hubungan asimetri informasi terhadap kesenjangan anggaran sebesar 0,000. Dengan demikian asimetri informasi merupakan mediator hubungan partisipasi terhadap kesenjangan anggaran.

Disisi lain penelitian ini memberikan bukti empirik bahwa insentif bukan sebagai mediator hubungan asimetri informasi terhadap kesenjangan anggaran.. Dengan demikian menunjukan bahwa insentif bukan mediator hubungan asimetri informasi terhadap kesenjangan anggaran.

Hasil ini memberikan bukti bahwa pada kasus kesenjangan anggaran Pendapatan Asli Daerah faktor yang lebih dominan untuk mendorong terjadinya kesenjangan anggaran adalah asimetri informasi. asimetri informasi adalah mediator yang cukup besar untuk mendorong terjadinya kesenjangan anggaran dibandingkan insentif. Maka jika melihat pada kasus kesenjangan anggaran antara organisasi pemerintah yang berorientasi profit dengan organisasi privat yang berorientasi profit terlihat bahwa motivasi ekonomi berupa insentif bukanlah faktor yang dominan yang mendorong terjadinya kesenjangan anggaran.

\section{Keterbatasan dan Saran}

Penelitian memiliki beberapa keterbatasan diantaranya menggunakan dua variabel yang digunakan untuk mengukur fenomena kesenjangan anggaran yang terjadi dalam perencanaan anggaran Pendapatan Asli Daerah. Menurut Onsi (1973) banyak faktor yang terkait dengan kesenjangan anggaran, sehingga penelitian selanjutnya perlu memperluas penggunaan variabel dalam konteks kesenjangan anggaran Pendapatan Asli Daerah. Penelitian ini hanya mencakup lima Kabupaten dan satu Provinsi sehingga lemah dalam generalisasi simpulan maka saran untuk penelitian selanjutnya adalah meningkatkan atau menambah daerah yang akan diteliti agar generalisasi simpulan lebih kuat. Penelitian ini menggunakan metoda kuantitatif yang memiliki keterbatasan yaitu kurang mengeksplorasi secara mendalam mengapa variabel asimetri informasi lebih dominan dalam memediasi terjadinya kesenjangan anggaran dalam kasus Pendapatan Asli Daerah. Maka penelitian selanjutnya diharapkan dapat mengkombinasikan metoda kualitatif sehingga menjadi metoda campuran untuk memperkuat generalisasi dan menggali lebih dalam peran asimetri informasi dalam kasus kesenjangan anggaran Pendapatan Asli Daerah.

\section{DAFTAR PUSTAKA}

Anthony, R.N dan Govindarajan, V. 2005. Management Controls System, Edisi 11, penerjemah: $\quad$ F.X. Kurniawan Tjakrawala, dan Krista. Jakarta. Penerbit Salemba Empat.

Anthony, Robert N dan Govindarajan, Vijay. 2007. Management Control System 12 Edition. New York: McGraw-Hill Education.

Bento, A., \& Ferreira White, L. (2006). Budgeting, performance evaluation, and compensation: a performance management model. In Advances in Management Accounting (pp. 51-79). Emerald Group Publishing Limited.

Brownell, P. 1980. Participation in the Budgeting Process: When it Works and When it Doesn't. Journal of Accounting Literature. Vol. 1. Hal. $124-153$.

Chow, C. W., Cooper, J. C., \& Waller, W. S. 1988. Participative budgeting: Effects of a truth-inducing pay scheme and information asymmetry on slack and performance. Accounting Review, 111122. 


\section{JURNAL OPTIMUM, Volume 10, Nomor 1 Maret 2020}

Christensen, J. 1982. The determination of performance standards and participation. Journal of Accounting Research, 589-603.

Douglas, P., dan Wier, B. 2000. Integrating Ethical Dimensions into a Model of Budgetary Slack Creation. Journal of Business Ethics,28(3), 267-277. Retrieved from http://www.jstor.org/stable/25074417

Dunk, A. 1993. The Effect of Budget Emphasis and Information Asymmetry on the Relation between Budgetary Participation and Slack. The Accounting Review, 68(2), 400-410. Retrieved from http://www.jstor.org

Falikhatun. 2007. Interaksi Informasi Asimetri, Budaya Organisasi dan Group Cohesiveness dalam Hubungan antara Partisipasi Penganggaran dan Budgetary Slack (Studi Kasus pada Rumah Sakit Umum Daerah se Jawa Tengah. SNA X, No. 25,1-24.

Gibran, J. M., \& Sekwat, A. 2009. Continuing the Search For a Theory of Public Budgeting. Journal of Public Budgeting, Accounting \& Financial Management, 21(4), 617.

Gomez-Mejia, L., \& Wiseman, R. M. 1997. Reframing executive compensation: An assessment and outlook. Journal of Management, 23(3), 291-374.

Gudono. 2015. Analisis Data Multivariat. BPFE Universitas Gajah Mada.

Halim dan Kusufi. 2014. Teori, Konsep, dan Aplikasi Akuntansi Sektor Publik. Jakarta. Salemba Empat.

Hartono, Jogiyanto. 2011. Structural Equation Modeling berbasis varian dalam penelitian bisnis. Yogyakarta. UPP STIM YKPN

Harrell, A., dan Harrison, P. 1994. An incentive to shirk, privately held information, and managers' project evaluation decisions. Accounting, Organizations and Society, 19(7), 569577.
Jensen, M. C., \& Meckling, W. H. (1976). Theory of the firm: Managerial behavior, agency costs and ownership structure. Journal of financial economics, 3(4), 305-360.

Lowe, E.A., dan Shaw, R.W. 1968. An Analysis of Managerial Biasing: Evidence from the Company's Budgeting Process. Journal of Management Studies (October): 304-15.

Lukka, K. 1988. Budgetary Biasing in Organization: Theoritical Framework and Empirical Evidence. Accounting Organization and Society 13.pp 281-301.

Merchant. K. A. 1985. Budgeting and Propensity to Create Budgetary Slack. Accounting, Organization, and Society.

Milani. K. 1975. The Relationship of Participation in Budget Setting to Industrial Supervisor Performance and Attitudes: A Field Study. The Accounting Review.

Onsi, M. 1973. Factor Analysis of Behavioral Variables Affecting Budgetary Slack. The Accounting Review, 48(3), 535-548. Retrieved from http://www.jstor.org/stable/245151

Pepper, Alexander., Gore, Julie. 2012. Behavioral Agency Theory: New Foundation for Theorizing About Executive Compensation. Journal of Management Vol 41, Issue 4, pp. 10451068.

Pope, P.F. 1984. Information of Asymmetric in participative budgeting: A Bargaining Approach. Journal of Business Finance and Accounting 11 (Spring). Pp. 41-59

Peraturan Pemerintah Nomor 69 Tahun 2010

Schiff, M., dan Lewin, A. Y. 1970. The Impact of People Budgets. The Accounting Review.

Shields, J. F., dan Shields, M. D. 1998. Antecedents of participative budgeting, Accounting, Organizations and Society, 23, (1), 49-76

Siegel, G. dan Marconi, H.R. 1989. Antecedents and Consequences of 


\section{BUDI BARATA KUSUMA UTAMI, RUSDI AKBAR}

\section{Peran Mediasi Asimetri Informasi Dan Insentif Dalam Kasus Kesenjangan Anggaran}

\section{Pendapatan Asli Daerah}

participate budgeting: Evidence on the effects of asymmetrical information. Journal of Management Accounting Research. Sarota: Vol. 5. Pp.265.

Siegel, G. dan Marconi, H.R. 1989. Behavioral Accounting. South Western Publishing, Co. Cincinnati, $\mathrm{OH}$.

Young, S.M. 1985. Participative Budgeting: The effect of Risk Aversion and Asymmetric Information on Budgetary Slack. Journal of Accounting Research. Auntum 23: pp:829-842. 